\title{
Mortality due to cutaneous melanoma in south region of Brazil: a spatial approach*
}

\author{
Flávia Regina Ferreira ${ }^{1}$
}

\author{
Luiz Fernando Costa Nascimento ${ }^{1}$
}

DOI: http://dx.doi.org/10.1590/abd1806-4841.20165122

\begin{abstract}
BACKGROUND: Cutaneous melanoma is a skin cancer with low incidence but high mortality rates. The South region of Brazil has the highest death rates by melanoma per 100,000 inhabitants of the country. Little is known about the spatial distribution of this malignancy in southern Brazil.

OBJECTIVEs: Identify the spatial patterns of deaths from cutaneous melanoma in South region of Brazil, using geoprocessing tools. METHODS: This is an ecological and exploratory study of death information by cutaneous melanoma obtained from portal Datasus, for Brazil's southern region, from January 2008 to December 2012. Deaths were separated by gender and rates per 100,000 inhabitants were calculated and used to compile thematic maps, Moran maps and Kernel maps, using TerraView software. It was adopted an alpha $=5 \%$.

RESUlTS: There were data on 2378 deaths from cutaneous melanoma in the study period. High rates were identified in the northern and littoral regions of Rio Grande do Sul; the northeast of Santa Catarina; and west of Paraná - for the total population, with minor differences detected and indicated regarding gender. The global Moran index presented p-values of $0.03,0.04$ and 0.03, respectively, for male, female and overall deaths. All the micro-regions that showed high priority for intervention were detected in the Rio Grande do Sul.

CONCLUSION: Spatial clusters of micro-regions with high death rates from cutaneous melanoma in South region of Brazil were identified, serving as an important tool for health managers.
\end{abstract}

Keywords: Geographic information systems; Melanoma; Mortality; Spatial analysis

\section{INTRODUCTION}

Melanoma is a malignant tumor that occurs due to the atypical transformation of melanocytes, pigmented dendritic cells, arranged in different anatomical locations: skin, eye, epithelial lining of the nasal cavity, oropharynx, anus, vagina and urinary tract. ${ }^{1,2}$

Cutaneous melanoma (CM) is the most frequent (91.2\%) and, despite representing only $3 \%$ to $4 \%$ of malignant skin tumors, it is considered the most serious type, because of its high rates of morbidity and mortality. ${ }^{1,2}$

The past decades presented a dramatic increase in its incidence worldwide, particularly in Caucasians. ${ }^{1,3-5}$ In this population, melanoma incidence rate increased from 7.5 cases/100,000 inhabitants in 1973 to 21.9 cases/100,000 inhabitants in $2002 .{ }^{4}$ Changes in sun exposure habits and people's lifestyle, with more outdoor leisure time and an increased tendency to use less clothes, are considered the main reasons for this occurrence. ${ }^{5,6}$
In Brazil, epidemiological data are scarce. ${ }^{1}$ According to estimates from the National Cancer Institute (INCA) in 2014, the incidence of CM would be 2,960 new cases in men and 2,930 new cases in women. The highest estimated rates in men (920 new cases) and women (880 new cases) are found in the South region, possibly due to the population profile of light skin in this region of the country. In this region, $\mathrm{CM}$ is already one of the top 10 cancers with highest estimated incidence for 2014 among women. ${ }^{7}$

The main risk factors for the development of $\mathrm{CM}$ result from the combination of constitutional/genetic and environmental factors, of which the skin color is the main one. ${ }^{1,8}$ Thus, are considered risk factors for CM: skin types I and II of the Fitzpatrick classification, sunburn history in childhood (excessive sun exposure), presence of multiple melanocytic nevi, presence of atypical or dysplastic nevi (higher risk when multiple), important photodamage, immunosuppression, prior personal history of melanoma or other

Received on 11.09.2015.

Approved by the Advisory Board and accepted for publication on 30.10.2015.

* Study conducted at Universidade de Taubaté (Unitau) - Taubaté (SP), Brazil Financial Support: None.

Conflict of Interest: None.

1 Universidade de Taubaté (Unitau) - Taubaté (SP), Brazil.

(C)2016 by Anais Brasileiros de Dermatologia 
skin cancer, as well as familial history of melanoma. ${ }^{1,4,8}$ Mutations in genes, such as CDKN2a, CDK4, and BRAF, and low penetrance genes, such as MC1R, have also been associated with melanoma development. ${ }^{8,9}$

The annual incidence rates of melanoma per 100,000 inhabitants, estimated in the capitals of South region of Brazil by gender in 2014 by INCA, were: 8.3 for males (M) and 7.8 for females (F) in Curitiba (PR); 9.6 (M) and 11.1 (F) in Florianópolis (SC); and 10.3 (M) and $9.6(\mathrm{~F})$ in Porto Alegre (RS). ${ }^{7}$

Regarding melanoma mortality in Brazil in 2012, data by region are: $0.26 / 100,000$ inhabitants in the North; 0.35/100,000 inhabitants in the Northeast; $0.90 / 100,000$ inhabitants in the Southeast; $1.74 / 100,000$ inhabitants in the South; and 0.64/100,000 inhabitants in the Midwest. ${ }^{10,11}$

The geoprocessing has become a useful tool in public health as it allows observing events in a spatialized form, that is, arranged in space. Therefore, it allows the identification of clusters with greater occurrence of some outcome and the visualization of the distribution of these events by the managers, guiding decision making. ${ }^{12-15}$

Therefore, the objective of this study was to identify spatial patterns of deaths from CM in the South region of Brazil.

\section{METHODS}

This is an ecological (based on population data) and exploratory study on CM deaths in the South region of Brazil occurred from January 2008 to December 2012. This five-year period was chosen to minimize possible fluctuations in the data.

The South region of Brazil is composed by the states of Paraná, Santa Catarina and Rio Grande do Sul, which are subdivided into a total of 94 micro-regions. The South region has land area of $576,409.6 \mathrm{~km}^{2}$ and is considered the smallest Brazilian region. However, it is the third most populous macro-region of the country, with approximately 27.5 million inhabitants. The European immigration in end of the nineteenth century contributed greatly to the development of the economy of this region, based on small and medium rural property of polyculture. Rio Grande do Sul received Italians, Slavs and German immigrants. In Santa Catarina, Azoreans settled the coast; Germans, the northern region; and Italian, the upland and the western portion. In Paraná, there were migrations of Italians, Germans and Japaneses. The states of the Brazilian South Region are recognized by the quality of life that they provide to their inhabitants, and the region has the best infant mortality, education and health indicators in the country, in addition to retaining the second highest per capita income, second only to the Southeast. ${ }^{16}$

The digital grid of the South micro-regions was obtained from the Brazilian Institute of Geography and Statistics (IBGE). IBGE's regions are built by municipalities with similar socioeconomic and demographic characteristics.

Through the Datasus website, data on deaths from $\mathrm{CM}$ were obtained of individuals of all ages, living in all the micro-regions of the South and separated by gender. The population in 2010 of each of the 94 micro-regions was also obtained in this website. These data were multiplied by five, then obtaining an estimate for the five years of the study. Thus, death rates were calculated per 100,000 inhabitants for further geostatistics analysis.
Through spatial analysis, thematic maps were built and values of the Moran's index (Moran's I) were also obtained.

The global Moran's I was obtained in order to verify if the death rates from $\mathrm{CM}$, according to the micro-regions, had spatial correlation with the values of the rates provided by the neighboring micro-regions, considering the South Region. This index establishes how independent a value observed in a region is from the values of this same variable in neighboring locations, determining, in positive cases, a positive spatial autocorrelation. Values close to 1 show similarity between micro-regions and values close to -1 show dissimilarity.

Thematic maps were built with death rates from $\mathrm{CM}$ according to gender and to total population, in quartiles, keeping the same intervals of these rates for further comparison. In addition, Moran and Kernel maps were also built for male, female and total population. Moran maps were intended to demonstrate which micro-regions presented low or high priority for intervention to reduce the event under study (death from CM). Kernel map is a statistical method that allows estimating deaths density by smoothing of rates, identifying hot spots (areas with high density of outcomes). Kernel estimator in this study used 150 columns, quartic and density function. The precision and the slices used were in number of 10 .

Being an ecological study, in which the subject is not identified, submission to the Institutional Review Board (IRB) was waived.

Spatial analysis was developed using the TerraView 4.2.2 program, provided by the National Institute for Space Research (INPE).

\section{RESULTS}

Data on 2378 deaths from CM were obtained from Datasus website for the period from January 2008 to December 2012: 799 (33.6\%) in Paraná, 1,023 (43\%) in Rio Grande do Sul and 556 (23.4\%) in Santa Catarina. Among the information obtained, 1388 (58.4\%) referred to male patients.

Mean values of death rates from CM per 100,000 inhabitants, with standard deviations, minimum and maximum values and Moran's index with $\mathrm{p}$ values, according to gender and total population, are shown in table 1.

Thematic maps created from male, female and total death rates are shown in figure 1.

It is noteworthy that high death rates (10 per 100,000 inhabitants and more) are concentrated in the north and coastal regions of Rio Grande do Sul, northeast of Santa Catarina and west of Paraná for the total population (Figure 1A). For males (Figure 1B), besides the previous distribution, it was also encompassed micro-regions in the center of Rio Grande do Sul and west of Santa Catarina. For females (Figure 1C), we noticed a larger number of micro-regions with low rates (3 per 100,000 inhabitants or less) in Paraná and Santa Catarina.

Only the micro-region of Cerro Azul, in Parana, presented a zero rate, i.e., no case of death from $\mathrm{CM}$ was reported during the study period. The regions of Faxinal and Assaí, also in Paraná, and Xanxerê, in Santa Catarina, also presented a zero rate, but only for females.

Moran maps for male, female and total population are presented in figure 2 and identify micro-regions with high and low priority for intervention. 
TABLE 1: Mean values of death rates by cutaneous melanoma per 100,000 inhabitants, with their standard deviations, minimum and maximum values and Moran's index, with p values, according to gender and total population. South Region, Brazil, 2008-2012

\begin{tabular}{llll}
\hline & Total population & Male population & Female population \\
\hline Mean (sd) & $1.73(0.96)$ & $2.01(1.31)$ & $1.45(0.88)$ \\
Min. and Max. values & $0-5.68$ & $0-8.68$ & $0-3.94$ \\
Moran's index & 0.17 & 0.15 & 0.12 \\
P value & 0.03 & 0.03 & 0.04
\end{tabular}

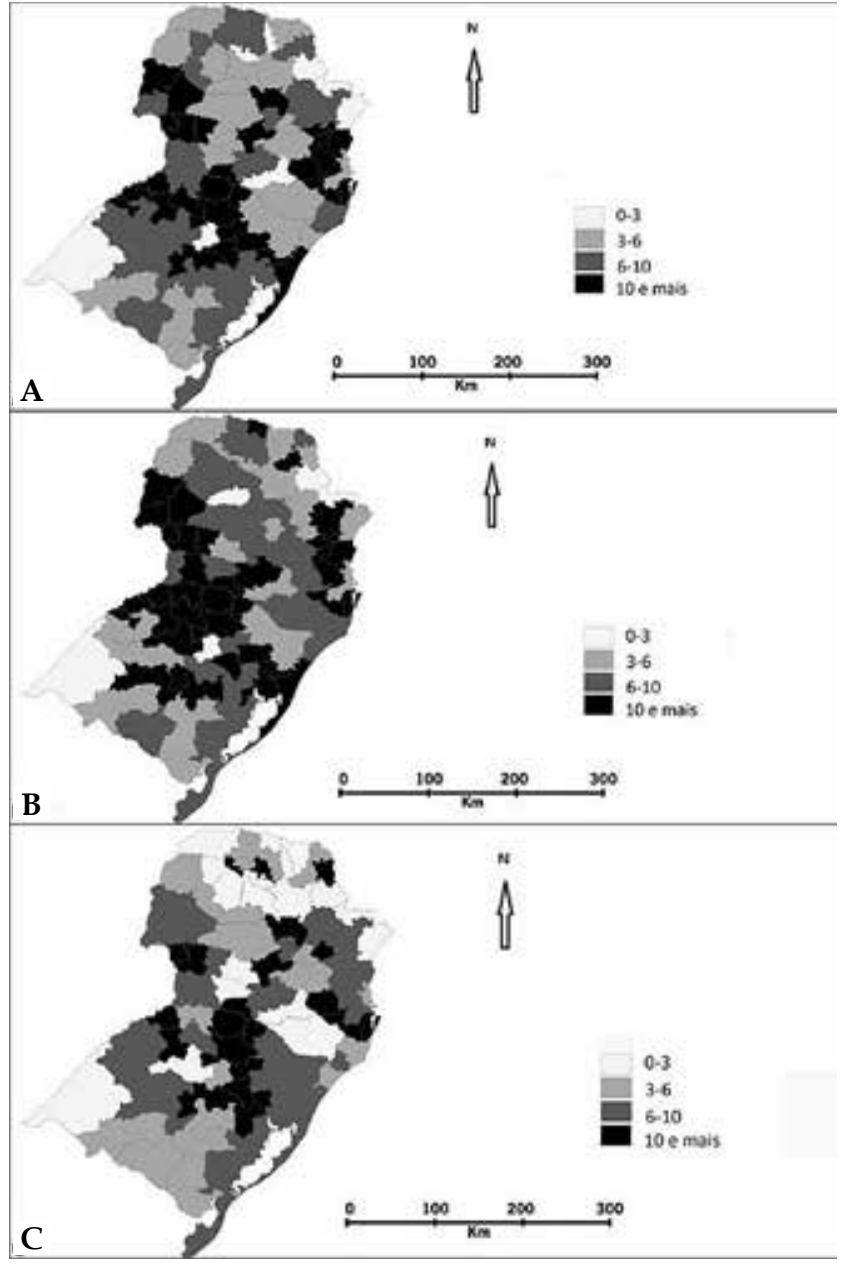

Figure 1: Death rates by cutaneous melanoma per 100,000 inhabitants: A) Total population; B) Male population; C) Female population. South Region, Brazil, 2008-2012

Figure 2A refers to the total population and allows to identify five micro-regions in Rio Grande do Sul (Erechim, Frederico Westphalen, Carazinho, Passo Fundo and Cruz Alta) that were located in Quadrant A-A (high priority for intervention). In figure $2 \mathrm{~B}$, referring to male gender, we observed the same distribution of micro-regions with high priority for intervention. For females (Figure 2C), also five micro-regions were identified as high priority for intervention, two of them (Erechim and Passo Fundo) coinciding

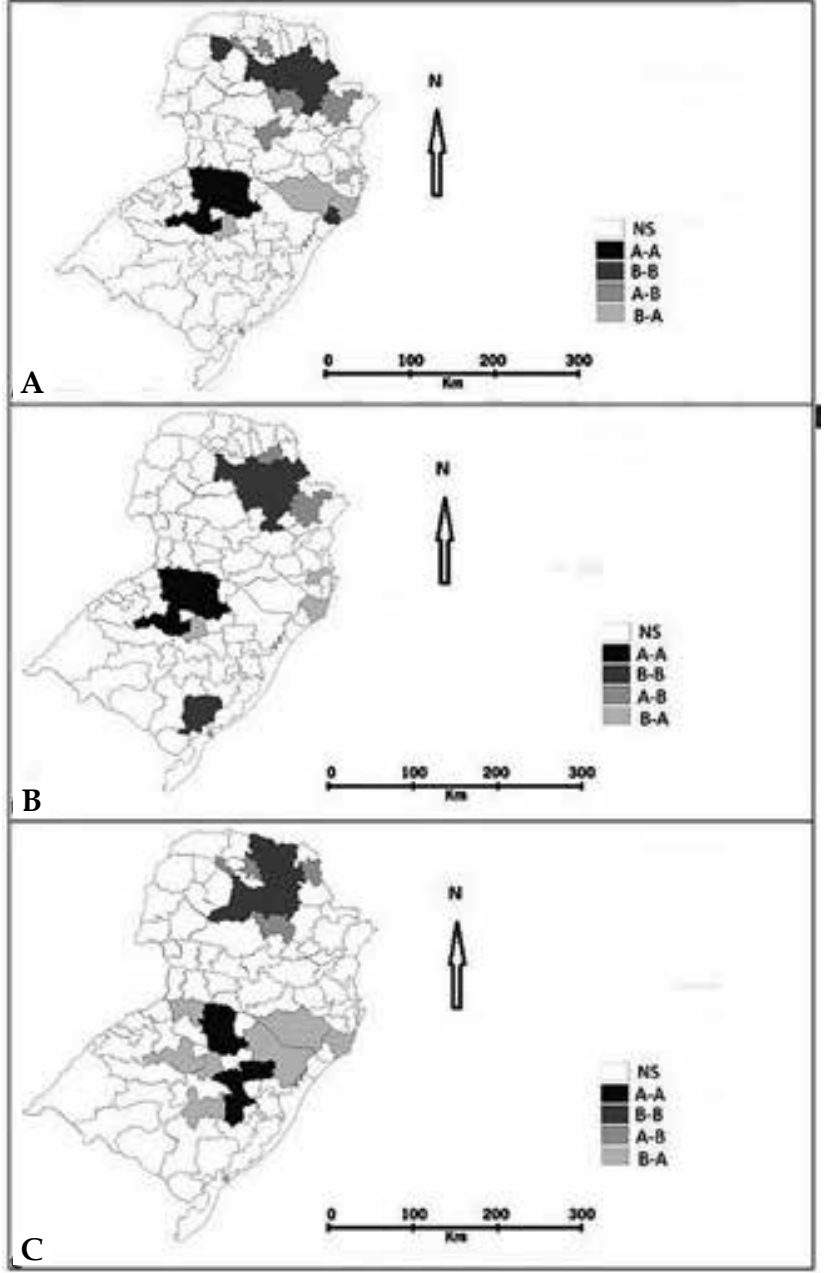

Figure 2: Moran maps identifying micro-regions with high and low priority for intervention: A) Total population; B) Male population; C) Female population. South Region, Brazil, 2008-2012

with those of the male and the total population and three (Caxias do Sul, Lajeado-Estrela and São Jerônimo) not coinciding.

Kernel map for the total population (Figure 3A) presented two hot spots: one in the north region of Rio Grande do Sul, extending to the northeast of this state, and another on the coast of Santa Catarina, extending to the southeast of Paraná. For males (Figure 3B), the Kernel map is similar, with lower density mainly in the northeast of Rio Grande do Sul. For females (Figure 3C), we observed a Kernel map almost superimposing the total population map. 


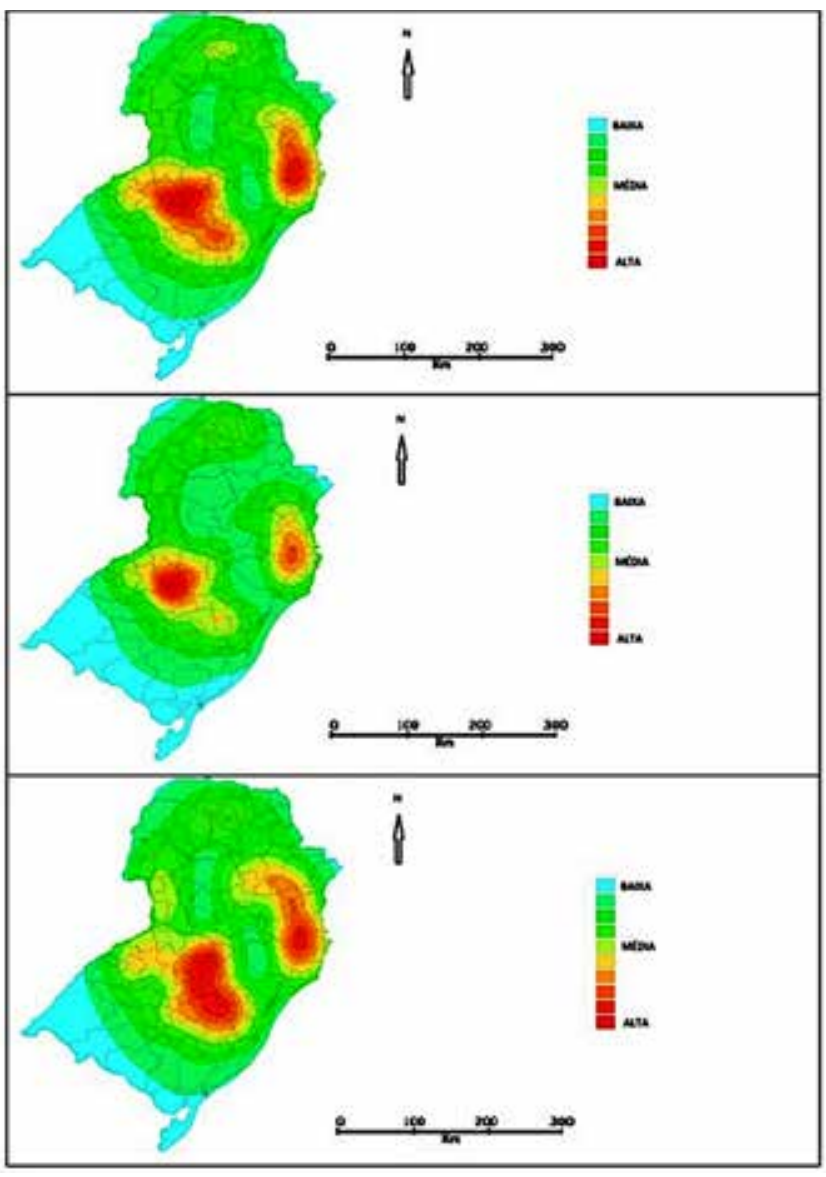

Figure 3: Kernel maps according to the densities of death rates by cutaneous melanoma: A) Total population; B) Male population; C) Female population. South Region, Brazil, 2008-2012

\section{DISCUSSION}

This study identified different spatial patterns for death rates by $\mathrm{CM}$ in South region of Brazil according to male, female and total population. It also allowed identifying micro-regions with high priority for intervention aiming at decreasing these rates.

The importance of using geoprocessing tools has been shown in studies of neonatal mortality, tuberculosis and pneumonia, among others, and more recently also on cutaneous melanoma with data from the state of São Paulo. ${ }^{12-15}$

Despite representing only $3 \%$ to $4 \%$ of skin cancers in Brazil, $\mathrm{CM}$ is responsible for over $75 \%$ of deaths and is a matter of great importance to the national public health, making imperative the recognition of areas with the highest occurrence and death rates, which would require major interventions. ${ }^{17-19}$

The South Region was chosen due to a higher prevalence of deaths per 100,000 inhabitants (1.74) compared to other Brazilian regions, such as Southeast and Northeast. This rate is close to European standards (Central Europe), in which the mortality rate is approximately 2.6 among men and 1.6 among women. ${ }^{5,10,11}$
In the study period, data of 2,378 deaths from CM were obtained, of which $58.4 \%$ referred to male gender. The highest death rates observed in this gender agreed with the national and international literature, which points out male gender as a bad prognostic factor for this tumor. ${ }^{20-25}$ Behavioral differences between genders (self-examination, medical care demand), detection and late $\mathrm{CM}$ diagnosis among men in addition to the genetic characteristics of each gender can justify this occurrence.

The spatial distribution of mortality is difficult to compare given the scarcity of similar studies.

The highest mortality rates occurred in micro-regions with predominance of light-skinned population (north of Rio Grande do Sul and east and west of Santa Catarina), agreeing with Borges et al. findings ${ }^{5}$ and corroborating ethnicity as one of the main risk factors for CM.

The authors agree with the proposition of the literature that some of the reasons for the high prevalence of melanoma in the South region of Brazil, which are also reflected in higher death rates found in this region, may be the composition and habits of its population: mainly Caucasian arising from intense immigration, especially from Central Europe, with little or no miscegenation in some areas (due to geographic, social and cultural reasons), exposed to solar radiation for several months a year because of weather conditions as well as labor and leisure options. ${ }^{8}$ In the Midwest region of Brazil, the city of Goiania presents a much lower incidence of melanoma than the North region of Australia, despite being in a similar latitude, reinforcing the importance of ethnic/racial miscegenation and exogenous factors, such as lifestyle (habits), of each population in the genesis of melanoma. ${ }^{20}$

Unlike incidence, which is increasing, death rate from melanoma shows a global trend towards stabilization and decline, possibly attributed to early diagnosis (success of prevention programs), to proper conduct and to best therapeutic resources. ${ }^{4,6}$ In Brazil, there is still an upward trend. ${ }^{21,22}$ A study conducted in the country showed a tendency to stability among women and growth among men. ${ }^{20}$

Moran maps obtained allow a more objective view of the micro-regions in the South region of Brazil that present high or low need for intervention. Micro-regions such as Erechim, Frederico Westphalen, Carazinho, Passo Fundo and Cruz Alta, in addition to Caxias do Sul, Lajeado-Estrela and São Jerônimo, have a high need for intervention. They correspond to micro-regions still with marked agricultural and agro-industrial activity, with small familial agro-industries (corn, beans, wheat and soybeans) and also large numbers of European immigrants, mostly German and Italians from the North.

Kernel map allowed the identification of a high density of deaths from CM in the north and northeast of Rio Grande do Sul and coast of Santa Catarina, extending to the southeast of Paraná, with little difference between genders. It also showed, together with the Moran maps, where the authorities should focus their efforts to minimize the occurrence of this event.

A possible limitation of this study resided in the possibility of incorrect or incomplete filling of death certificates regarding diagnosis and home address of the individuals. This data feed Datasus website and may therefore have led to an underestimation or over- 
estimation of the actual death rates from this tumor. On the other hand, the pooled analysis of data of five years allowed the identification of spatial clusters with higher mortality rates in the South region of Brazil, minimizing fluctuations in these rates.

\section{CONCLUSION}

This study allowed identifying spatial clusters of micro-regions with high $\mathrm{CM}$ mortality rates in the South region of Brazil, being an important subsidy to health managers in planning interventions that enable changing this situation in future studies. $\square$

\section{REFERENCES}

1. Almeida FA, Almeida G00, Michalany NS. Melanoma cutâneo. In: Neves RG, Lupi 0, Talhari S. Câncer da Pele. Rio de Janeiro: MEDSI; 2001. p. 225-32.

2. Pereira FBC. Melanoma primário extracutâneo. In: Neves RG, Lupi 0, Talhari S. Câncer da Pele. Rio de Janeiro: MEDSl; 2001. p. 250-59.

3. Nasser N. Epidemiologia do Melanoma Maligno em Blumenau - SC. An Bras Dermatol. 1993:68:17-20.

4. Nasser N. Melanoma cutâneo - estudo epidemiológico de 30 anos em cidade do sul do Brasil, de 1980-2009. An Bras Dermatol. 2011;86:932-41.

5. Borges SZ, Bakos L, Cartell A, Wagner M, Agostini A, Lersch E. Distribution of clinical-pathological types of cutaneous melanomas and mortality rate in the region of Passo Fundo, RS, Brazil. Int J Dermatol. 2007;46:679-86.

6. Lasithiotakis KG, Leiter U, Gorkievicz R, Eigentler T, Breuninger H, Metzler G, et al. The incidence and mortality of cutaneous melanoma in Southern Germany: trends by anatomic site and pathologic characteristics, 1976 to 2003. Cancer. 2006;107:1331-9.

7. Saúde.sp.gov.br [Internet]. Brasil. Ministério da Saúde. Instituto Nacional de Câncer José Alencar Gomes da Silva. Estimativa 2014: incidência de câncer no Brasil. Rio de Janeiro: INCA; 2014 [acesso 8 Mar 2016]. Disponível em: http:// www.saude.sp.gov.br/resources/ses/perfil/gestor/homepage/outros-destaques/ estimativa-de-incidencia-de-cancer-2014/estimativa_cancer_24042014.pdf

8. Martins-Costa GM, Bonamigo RR, Menegat AP, Costa LLM, Bonfá R, Grazziotin TC. Melanoma cutâneo primário: confirmações e novidades. Revista da AMRIGS. 2013:57:208-12.

9. Udayakumar D, Tsao H. Melanoma genetics: an update on risk-associated genes. Hematol Oncol Clin North Am. 2009;23:415-29.

10. Datasus. gov. br [Internet]. Informações de Saúde. Estatísticas Vitais. [acesso ago 2015]. Disponível em: http://tabnet.datasus.gov.br/cgi/tabcgi.exe?sim/cnv/ obt10uf.def

11. Datasus.gov.br [Internet]. Informações de Saúde. Demográficas e Socioeconômicas. [acesso 11 ago 2015]. Disponível em: http://tabnet.datasus. gov.br/cgi/tabcgi.exe?ibge/cnv/popuf.def

12. Almeida MCS, Gomes CMS, Nascimento LFC. Spatial analysis of neonatal mortality in the state of São Paulo, 2006-2010. Rev Paul Pediatr. 2014;32:374-80.

13. Venâncio TS, Tuan TS, Nascimento LF. Incidence of tuberculosis in children in the state of São Paulo, Brazil, under spatial approach. Cien Saude Colet. 2015;20:1541-7.

14. Mukai AO, Nascimento LFC, Alves KSC Análise espacial das internações por pneumonia na região do Vale do Paraíba (SP). J Bras Pneumol. 2009;35:753-8.

15. Amâncio CT, Nascimento LFC. Melanoma cutâneo no estado de São Paulo: uma abordagem espacial. An Bras Dermatol. 2014; 89:442-6.

16. Mundoeducacao.com [Internet]. Geografia Humana do Brasil. A população da região Sul. [acesso 10 Ago 2015]. Disponível em: http://www.mundoeducacao. com/geografia/a- populacao-regiao-sul.htm
17. Inca.gov.br [Internet]. Ministério da Saúde. Instituto Nacional do Câncer. Tipos de Câncer. Pele Melanoma. [acesso 12 Ago 2015]. Disponível em: http://www2.inca. gov.br/wps/wcm/connect/tiposdecancer/site/home/pele_melanoma

18. Moreno $\mathrm{M}$, Conte $\mathrm{B}$, Menegat $\mathrm{E}$. Diferenças Clínico-Epidemiológicas entre Pacientes Masculinos e Femininos com Diagnóstico de Melanoma Cutâneo no oeste de Santa Catarina. Rev Bras Cancer. 2015;61:15-21.

19. Weimann ETS, Silvino TST, Matos LS, Simião AL, Costa A. Delineamento epidemiológico dos casos de melanoma cutâneo atendidos em um hospital terciário de Campinas, São Paulo, Brasil. Surg Cosmet Dermatol. 2014;6:262-6.

20. Sortino-Rachou AM, Curado MP, Latorre MRDO. Melanoma cutâneo: estudo de base populacional em Goiânia, Brasil, de 1988 a 2000. An Bras Dermatol. 2006;81:449-55.

21. Murussi N, Peres M, Bakos L, Moreira L, Freitag F, Amaral J, et al. Mortalidade ascendente por melanoma cutâneo no Rio Grande do Sul. Rev HCPA. 2007;27:605.

22. Quintela Mendes GL. Melanoma cutâneo invasivo: Mortalidade no Brasil sobrevida hospitalar em centro de referência oncológica no Rio de Janeiro [dissertação]. Rio de Janeiro (RJ): Fiocruz; 2010.

23. de Vries E, Schouten LJ, Visser O, Eggermont AM, Coebergh JW; Working Group of Regional Cancer Registries. Rising trends in the incidence of and mortality from cutaneous melanoma in the Netherlands: a Northwest to Southeast gradient? Eur J Cancer. 2003;39:1439-46

24. Garbe C, Orfanos CE. Epidemiology of malignant melanoma in central Europe: Risk factors and prognostic predictors. Results of the Central Malignant Melanoma Registry of the German Dermatological Society. Pigment Cell Res. 1992;Suppl 2:285-94.

25. Giles GG, Armstrong BK, Burton RC, Staples MP, Thursfield VJ. Has mortality from melanoma stopped rising in Australia? BMJ. 1996;312:1121-5.

How to cite this article: Ferreira FR, Nascimento LFC. Mortality due to cutaneous melanoma in south region of Brazil: a spatial approach. An Bras Dermatol. 2016;91(4):437-41. 